\title{
The Leading Universities' Social Responsibility and Regional Development
}

\author{
Andrei G. Shelomentsev ${ }^{\mathrm{a}}$, Olga A. Kozlova ${ }^{\mathrm{a}}$, Svetlana V. Doroshenko ${ }^{\mathrm{a}}$, \\ Elena S. Kiseleva ${ }^{\mathrm{b}}$ \\ * Corresponding author: Andrei G. Shelomentsev, chel61@mail.ru \\ ${ }^{a}$ Institute of Economics, Ural Branch of Russian Academy of Sciences, 29 Moskovskaya str., Yekaterinburg, \\ Russia,chel61@mail.ru,8-912-602-7961 \\ ${ }^{b}$ National Research Tomsk Polytechnic University, 30 Lenin ave., Tomsk, Russia, rosakiss@yandex.ru, 8-913-843-1246
}

\begin{abstract}
http://dx.doi.org/10.15405/epsbs.2017.01.83

The paper deals with processes of development of a university's social responsibility in the regional community. The content of ten web-sites of Russia's federal universities and of official sites of regional authorities of their respective locations was taken as the initial empiric material. Theoretical analysis of basic viewpoints on the nature of buildup of universities' social responsibility was conducted. Basing on the socio-cultural approach to analysis of the mission and lines of the universities' activities, the authors generalized modern practices of social responsibility realization and gave insight into prospective lines of the universities' activity in the context of socio-economic development of Russian regions. As a working hypothesis, it has been assumed that it is human and professional experience of regional leaders that has considerable influence on formation of universities' and regions' mutual social responsibility for realization of socio-economic objectives of the regional development. Finally, conclusions about horizons and ways of enhancement of the role of social responsibility within the system of interrelations between universities and regions were formulated.
\end{abstract}

(C) 2017 Published by Future Academy www.FutureAcademy.org.uk

Keywords: Social responsibility, University, regional development.

\section{Introduction}

The project approach to development of the nation-wide system of higher professional education became the main stream of reforming education in Russia, whereas in the liberal market-oriented conception which bases on a state's pragmatic attitude to the higher education system, a university is regarded as a market institution destined for rendering educational services, and so should be considered 
as a place for training qualified human resources, forming their professional competences and new knowledge.

By this approach, public funding should be realized merely by directions of professional training of specialists most significant for the national economy development. No doubt, it is somehow logical unless we plunge too deep into the issue of educational reforms in Russia.

However, another position also exists which differs from the official course of reforming of the national higher school. As it is mentioned by many national researchers (Lavrov, \& Stepanova, 2012; Smirnov, 2012), each university is a social institution integrated into the system of social relations and realizing a complex of long-time programmes aimed at development of personnel and intellectual potential of the region, transfer of innovations into the regional economy, maintaining of socio-cultural identity which determine quality of socio-economic space of the regional community. Moreover, during a period of global economic crisis universities become a most important element of the region's social, cultural and innovation development. This article is aimed at searching most efficient mechanisms and tools of interaction between universities and regions.

\section{Methods and materials}

As a methodological frame of the study allowing determining intrinsic characteristics of the transformation of functions of a modern university as a social institution, the socio-cultural approach has been chosen which, for analysis of buildup and development of universities' social responsibility, is focusing on historically formed and stable socio-axiological elements setting objective borders for transformation of the university's functions in social development.

As it is, comparative evaluations are used as the basic method of solving the task set out in this article; these evaluations are confined, first, in correlation of general aspects of various universities' development between each other; second, in correlation of the authorities' and universities' strategic priorities within one region; and third, in evaluations of main evolutional trends of the leading universities' role in development of sub-federal entities in comparison with their place as defined by program documents of development of Russia's educational system.

On basis of extracting structural, administrative and socio-cultural features and differences, the task of determining ways and methods of integrating universities into the strategy of regional development by means of further development of social responsibility has been formulated and is now in process of solving.

The choice was made in favour of federal universities as objects of the study. By now, pursuant to Federal Law of the Russian Federation dd. 11th February, 2009 No. 18-FZ, a network of ten federal universities is founded which are located in federal circuits. All federal universities were created by joining of more than 40 educational and scientific institutions of the regions. The government of the Russian Federation approved development programmes of federal universities as a backbone structure of the higher professional education system of Russia. As a result, at present the total number of students studying in federal universities is equal to appr. 340 thousand, while the number of professors and teachers is about 27 thousand, $60 \%$ of them possess doctor's and candidate's degrees; the structure of federal universities covers 151 institutes (academies, schools), 29 branches, 14 colleges and voca- 
http://dx.doi.org/10.15405/epsbs.2017.01.83

eISSN: 2357-1330 / Corresponding Author: Andrei G. Shelomentsev

Selection and peer-review under responsibility of the Organizing Committee of the conference

tional schools; and the overall amount of scientific and RD works performed by federal universities in 2014 totalled 5.436,5 million roubles (The national rating of universities, 2015; Rating universities in Russia, 2015).

The concept of creation and governmental support of development of federal universities was based on the idea of advancement of affordable high-quality education to remote territories by means of foundation and development of large-scale innovation scientific-educational complexes - federal universities - in federal circuits. At the same time, formation and development of the competitive human capital in federal circuits on basis of creation and realization of innovation services and developments were seen as the strategic mission of a federal university.

Various elements of mutual social responsibility of federal universities and regions of the Russian Federation were inherently laid in the Conception. For example, the conceptions of founding universities assigned, so to say, influence areas to federal universities: Northern Arctic Federal University (SAFU) in Northern-Arctic region, Far-Eastern Federal University (DVFU) in Asian-Pacific region, Southern Federal University (YuFU) in the south of Russia and in Central Asia, Baltic Federal University (BFU) in East-European region and Baltic states; Kazan (Volga region) Federal University (K(P)FU) is focused on assistance to the dialogue of Christendom and Dar al-Islam ("Muslim world"); Ural Federal University (UrFU) is aimed at re-industrialization of the Ural region, while North-Caucasian Federal University (SKFU) - at an inter-cultural dialogue in the "hot region". With taking it into account, two universities were founded in each of two federal circuits, North-Western and Far-Eastern (Kudryashov, 2014).

Thus, choice of the network of Russia's federal universities as the object for analysis of developing modern forms of social responsibility in such a socially significant sphere of our society as education was stipulated, first, by their today's leading role in the system of higher professional education within their dynamics and scales, which is the most important, in Russia's regions; second, by reflection, in their development, of basic modern development trends of the modern system of higher professional education in Russia, of their contradictory and irreversible nature; third, by the observed processes of formation and step-by-step institutionalization of federal universities' and regions' social responsibility which is gradually transforming into a definite format of relations between management of universities and authorities of sub-federal entities and federal circuits. At the same time, it is important to note that the anticipatory developmental character of various forms of social responsibility was inherently laid into the idea of creating federal universities.

\section{Definition of social responsibility}

The conception of corporate social responsibility developed, first of all, for enhancement of the big business's social role in the society is at present the most actual for justification of the theoretical base of the social policy subjects' interrelations in terms of re-distribution of limited resources and thus providing possibility of harmonization of social relations. For instance, H. Bowen in his monograph The Social Responsibility of the Businessman defined it as realization of such a business policy or line of behaviour which would be preferable for the society's purposes and values (Bowen, 1953). 
A system approach to the social responsibility study is formulated in works by A. Carroll. According to his classification, four basic spheres of responsibility are singled out which are closely interconnected and mutually dependent between each other: economic, legal, ethic and philanthropic. The first sphere reflects the economic profit being the basic duty of the organization. The second sphere includes legal responsibility or observance of legislative frames established by the state. The third sphere is featured with ethic responsibility, with assuming the "do not harm" rule in line with the ethic and moral norms accepted by the society. The first sphere presents charity as the highest form of responsibility, including such measures as corporative social programmes (Carroll, 1991).

Later, by a number of studies, A. Carroll's model was transformed into a 3-sphere one (without the philanthropic component) and a provision was substantiated that any organization should combine all three spheres, whereas the actual CSR [Corporate Social Responsibility] level should depend on varieties of their combinations (Blagov, 2010). To determine purposes and solutions of strategic and tactic tasks of an organization's development and developing ideas of corporate social responsibility, I. Freeman elaborated the conception of accounting problems of shareholders, employees, customers and the social environment as a whole by companies' management; to Freeman's mind, it should ensure support of all stakeholders (Freeman, \& Hasnaoui, 2011), whereas a number of Russian researches consider two responsibility levels, obligatory and voluntary, which are examined externally and internally at the same time. An activity not touching upon the company's spheres of action and not being a response to consequences of the company's direct impact on the ecological and social environment was regarded as voluntary. As for obligatory one, it implies necessity of companies' management to respond to consequences of their influence (Morozova, 2011).

At the same time, a number of authors, while arguing against this point of view, see it more logical to assume that fulfilling legislative norms, paying taxes and social expenditures and following to environmental and social laws are covered by the business's obligatory responsibility which can be defined just as a base for development of corporate social responsibility having a supplementary character. Moreover, it can be expressed both in taking extra obligations for results of their basic activity prescribed in the company's strategy, mission, and ethical code, and be not related directly to the company’s basic activity (Shokola, \& Shraer, 2015).

The international practice defines corporate social responsibility as "entities' responsibility for their influence upon the society" (The strategy of the European Commission on CSR for 2011-2014, 2011), as a voluntary contribution of the business into development of the society in social, economic and ecological spheres, which is directly connected with companies' basic activities and extends beyond the borders of a statutory minimum. Thus, companies' activities in the field of corporate social responsibility is regarded as a pragmatic business line and is one of tools that allows enhancing the business reputation and the company's capitalization, establishing efficient and well-balanced relations with all influence group of the company: the state, shareholders, consumers, personnel, partners, local communities; also, it allows efficient managing of non-production risks (Shakhovoy, 2008). World Business Council for Sustainable Development suggests that under CSR one should understand adherence of the business to economic growth with simultaneous improving of living standards of workers and their families, as well as the whole society (WBCSD Stakeholder Dialogue on CSR, 1998). 
http://dx.doi.org/10.15405/epsbs.2017.01.83

eISSN: 2357-1330 / Corresponding Author: Andrei G. Shelomentsev

Selection and peer-review under responsibility of the Organizing Committee of the conference

The International Standard ISO 26000:2010 “Guidance on Social Responsibility” gives a universal definition, according to which social responsibility is "responsibility of an organization for the impacts of its decisions and activities on society and the environment, through transparent and ethical behaviour that contributes to sustainable development, including health and the welfare of society; takes into account the expectations of stakeholders; is in compliance with applicable law and consistent with international norms of behaviour; and is integrated throughout the organization and practiced in its relationships" (Moratis, \& Cochius, 2011). This international document helps companies and organizations to convert principles into efficient actions with taking into account the advanced experience in sphere of social responsibility in the global scale.

Thus, analysis and generalization of numerous definitions of corporate social responsibility allows characterizing this tool of social relations management as a system of principles and practical approaches o management and decision-making at an organization's level in terms of understanding one's responsibility to the society and environment.

\section{Universities' social responsibility}

With regard to universities as the object of our study, speaking that they ought to be socially responsible means acknowledging the position that inherently social responsibility is the thing they lack. However, education (and higher education especially) was always deemed in Russia as the most important source of public benefit, while universities were in charge for public development through forming values, definite types of culture and life reference points of their graduates. At present too, the level of education of a country's population is recognized in the whole of the world as one of the most significant indexes of the population's living standards and is correlated with economic success, health, stability of family relations, quality of social links, low criminality level, etc. (Hout, 2012).

During the Soviet period of Russia's history it was emphasized that training of specialists should be closely connected with requests of industrial production and needs of national economy. A welldeveloped system of interaction between high schools and enterprises (concluding agreements for passing of on-job training) and distribution of graduates in various spheres of economy and regions of the country was functioning. Another aspect of social responsibility was also formed in the shape of a widespread network of social infrastructure objects for employees and students of high schools, the social protection system, trade unions - i. e. the things that CSR researchers define as internal social responsibility.

Historically, first universities were based on the knowledge accessibility model for the elite only; however, development of higher education is closely connected with economic and public development, and universities' missions were developing for many centuries in order to respond to changing socio-economic and cultural needs of the society. The role and responsibility of universities are constantly growing in the modern world, which can be referred to improving of their accessibility for various social-demographic and income-defined population groups. Obviously, the more is the impact, the higher is the responsibility for results thereof. In this connection, a natural question arises: in what direction reformations in universities' activity are necessary. 
At present the significance of universities' social responsibility from the position of sustainable development and forming of their "third role" as related to active participation in the life of the regional community is actively discussed in numerous publications. In context of sustainable development, responsibility appears in its social-cultural dimensions. In the justice-oriented "new society" universities should perform an important role of a social institution, serve a cultural landmark for the society and contribute in situ to social development based on strengthening of generations' interrelation through upbringing of the youth and inoculation of universal human values (De Deus et al, 2015; Paleari, et al., 2015).

When examining functions of a university from the above mentioned positions, one can note its following peculiar features as those of a social institution: sustainable forms of interaction of many a man; ability for integration into the socio-cultural, scientific-technological and innovation space of the region; possessing of material and intellectual resources and conditions that are able to ensure efficient realization of social functions; ability for generation of cultural, moral and ecological norms of behaviour, and realization of monitoring of compliance thereof.

At the same time, it is the socially responsible line of a university's activity that is singled out as autonomous in methods of evaluation of the university's work when it is positioned as the key factor of development of the national innovation system and enhancing of the economy's competitive ability; thus, not only importance of this activity line is emphasized but also voluntary nature thereof (Chicharro et al., 2015).

It appears from the conducted analysis that universities' social responsibility is traditionally regarded as a voluntary split of responsibilities for satisfaction of public needs with official authorities. At the same time, the basic difference in the existing approaches lies in ideas on boundaries of social responsibility and universities' functions at realization thereof. In particular, from one viewpoint, a university performs its liabilities to the society in sufficient amount just by successfully managing all its activities (educational and scientific). Another point of view on this issue defines necessity of developing by universities of their own ethics of corporate social responsibility, similarly with large business structures.

Finland's experience is very illustrative for this. E.g., in 2001 the country's Industrialists and Businessmen Confederacy developed a model of corporate social responsibility including the three components: economic responsibility (achieving economic well-being of the society), ecological (following all ecological requirements aimed at saving the environment) and labour (creating new working places, enhancing the human potential). Further on, this model was taken as a basis for definition of universities' social responsibility. In 2004 Act on universities which is the basic legislative instrument governing activities of high school was revised; according to the modifications, universities were charged, apart from their conventional educational and research activities, with the so-called third role of high schools being their "social mission" (Universities Act 645/1997, 2004). Followers of applying the corporate social responsibility model to universities call their approach as "shareholder" approach. Recognition of such responsibility is reflected, first of all, in expansive rendering of the concept of a university’s social responsibility. 
http://dx.doi.org/10.15405/epsbs.2017.01.83

eISSN: 2357-1330 / Corresponding Author: Andrei G. Shelomentsev

Selection and peer-review under responsibility of the Organizing Committee of the conference

\section{Universities and regional development}

Strengthening of the "third role" results in the fact that not only the university becomes a participant of regional development, but representatives of local authorities, business and communities are members of the university's management. Simultaneously, a scope of tasks to be solved by the high school is being expanded. A good example of how "the third role" is realized is founding of special employment services under the university's control which develop the contact network with personnel bureaus of leading corporations and governmental institutions in purpose of successful employment of their graduates.

The Russia's latest two decades' experience in reforming high school shows that a university's compliance to formal indexes, as one item, and its responsibility to the society, as another one, are concepts lying in different planes. One can set a question: what is the society that is forming the university and higher education today? Does the university respond to social challenges emerging to the society? It is of interest here that among the significant amount of publications related to analysis of economic and organizational parameters featuring the quality of universities' functioning, there are very few studies wherein university graduates are regarded as carriers of not only definite occupational knowledge and competences but also of cultural values, national identity and personal social responsibility to the society and the country as a whole.

As definite authors state, the category of responsibility in respect to activity of a modern university can be regarded in two meanings. The first value can be referred as formal, and the second as contentrelated (Zabayev, \& Pavlyutkin, 2014). The first one is based on the idea of regulating the correspondence between formal indexes of official reports and the actual activity in the organization. The second meaning is based on the fact of interrelation between the university and the society. Development of conformance management industry which, as envisioned, was to make a university responsible and transparent, in reality leads to the inverse effect. The university ceases to see its mission as that of a public institution responsible for the future society, and becomes into a kind of a "perfect organization" focused entirely on achieving formal resulting parameters. So, comprehensive tools for conducting country-wide evaluation of universities are created for conducting results of various universities' activities: ratings, accreditation models, efficiency monitoring, etc.

Basing on the said above, the further logics of this paper lies on the following provisions.

Universities' social responsibility to the regions is considered in the system of their practical activity and relations with state authorities of sub-federal entities. At the same time, the activity approach should allow avoiding excessive theorification and substantiating conclusions with necessary factbased materials.

First, universities' social responsibility is regarded as a continuous process but not from the position of ad hoc characterizing interrelations between universities and state authorities.

Second, social responsibility of the university and the region is a mutual and multi-aspect phenomenon which may be regarded both from positions of education and from those of state authorities. 
Third, realization of the mutual responsibility of universities and state authorities is always under influence of subjective personality factor, in particular, of rectors' and region leaders' personal properties.

Fourth, social responsibility is not just a fragment of current activity of university corporations and regions but the most important priority of their long-term development, the practical realization whereof will depend on comprehensive understanding of the role of each one in the regional development.

\section{Missions of the leading universities of Russia}

The strategic mission of a federal university is forming and development of a competitive human capital in federal circuits on basis of creation and realization of innovation services and developments. Fulfilling of the strategic mission by federal universities is connected with solving of the following tasks: training of high-skilled specialists able to perform practical activity; creation of innovation technologies; assistance to growth of regions' socio-economical potential; influencing regions' innovative development via development of scientific researches in accordance with the regions' needs; providing possibility of continuous education for population of the regions; interaction with other participants of the regional development for realization of its mission.

The keystone of solving these tasks is the understanding of the place and role of the university in forming of social responsibility: how the latter is seen and realized by the university, with formation of the university's mission; how the university's social responsibility connects it with its region; how its activity is integrated into programmes and mechanisms of the regional development.

It would be logical to represent this understanding in the context of major content-based elements of social responsibility, including the conventional university values: qualitative education, regeneration of new knowledge, forming of a specialist's integral personality, and a contribution into development of the region's socio-economic and cultural space.

For instance, the mission of Volga Region Federal University is defined as "maintaining and development of enlightenment traditions in the vast region of encountering Europe's and Asia's cultures" (Kazan (Volga region) Federal University Development Programme, 2010).

Ural Federal University (Ural Federal University Development Programme, 2010) is aimed at "enhancing of international competitive ability of the Ural region and providing of re-industrialization, build-up of the human and scientific-technological potential, well-balanced renovation of traditional and development of post-industrial branches of Russia's economy, first of all, in the territory of Ural Federal circuit".

The mission of Siberian Federal University (Siberian Federal University Development Programme, 2015) runs as follows: creation of an advanced educational, scientific and innovation infrastructure, advancing of new trees of knowledge and technologies for solving issues of socio-economic development of Siberian Federal circuit, as well as forming of the human resourcing pool - competitive specialists in priority development lines of Siberia and the Russian Federation conforming to modern intellectual requirements and world standards.

Southern Federal University (Southern Federal University Development Programme, 2011) defines its mission as development of the scientific-educational and innovative space of Southern Federal cir- 
http://dx.doi.org/10.15405/epsbs.2017.01.83

eISSN: 2357-1330 / Corresponding Author: Andrei G. Shelomentsev

Selection and peer-review under responsibility of the Organizing Committee of the conference

cuit on basis of generation and transferring of scientific knowledge and technologies, maintaining and augmentation of cultural traditions and values.

Far-Eastern Federal University (Far Eastern Federal University Development Programme, 2010) sees its mission in contributing to cooperation of Asian-Pacific countries, their social and cultural prosperity, development of the region's young men on basis of education, augmentation of scientific knowledge and creation of new technologies.

The mission of North-Western Federal University (North-Eastern Federal University Development Programme, 2015) is stated as "upbringing of competitive specialists, performing researches and innovation-technological developments for buildup of the economically sustainable and socially developed sub-polar region, in order to provide high living standards and maintaining and development of the culture of nations from Russia's north-western regions”.

The mission of Northern (Arctic) Federal University (Northern (Arctic) Federal University Development Programme, 2015) is formulated as scientific and staff assistance for protection of Russia's geopolitical interests in Arctic by means of creating the system of continuous education, conducting Arctic-related researches and innovative technological developments, strategic partnership with the business community.

In North-Caucasian Federal University (North Caucasian Federal University Development Programme, 2012), the mission is stated in a quite ambitious manner: "by presenting unique possibilities in educational, scientific and cultural spheres, to form future leaders able to make a positive contribution into development of the country and the world".

Crimean Federal University (V.I. Vernadsky Crimean Federal University Development Programme, 2015) defines its mission as training of high-skilled specialists and consolidation of intellectual resources for solving tasks of sustainable development of Republic of Crimea and the city of Sevastopol.

The mission of Baltic Federal University (Immanuel Kant Baltic Federal University Development Programme, 2011) is disclosed through the functions performed by it on three levels: regional - integration of the science and education system into the exclave Kaliningrad Region for increasing of its competitive ability with innovative systems of European Union countries; federal - strengthening of Russian statehood and culture in the exclave region of Russia surrounded by EU, strengthening of relations with Russia's informational and innovative centres; international - cooperation in the scientific-innovative sphere with the partner universities of Europe for activation of transferring innovation and educational techniques, plus assistance to mobility of the young population of Russia.

The mentioned formulations of the federal universities' missions demonstrate their different understandings thereof, and thus they possess different ideas about social responsibility and their destination in their respective territories. The diversified character of these formulations is clearly seen:

- From the mega-mission (focusing on the entire world, Asian-Pacific countries, development of the enlightenment traditions, human rights protection, promotion of the society's progress);

- to the macro-mission (development of the Arctic, assistance to cultural development of the peoples of Russia, assistance to mobility of the young population of Russia);

- to the meso-mission (participation in solving of regional problems, renewal of traditional and development of post-industrial branches of Russia's economy, training of competitive specialists); 
- to the micro-mission (responsibility for maintaining the intellectual and staff potential, buildup of the education centre, cooperation with European universities, entering into the pool of the world leading universities, conducting R\&D).

Is this diversified and split-level understanding explicitly good? Possibly, it can take place for nonstate universities, as their foundation flowed from the founders' intention to fill niches in the state education system being under reforming.

But may the unified understanding of social responsibility be deemed necessary for state universities involved into routine fulfilling of the paid-up order for training specialists? To our mind, it is necessary for enhancing efficiency of the education system management. Realization of the following chain is needed: an order to the university for training a qualified specialist in demand - the high school's mission (social responsibility thereof for quality of the graduate's training) - the development strategy - agreeing the strategy with the region - the development programme - the realization technology.

The social responsibility in this chain is being formed gradually, in the mode of collective activity of all participants of the education process. It unites them, correlates their interests and thus forms the united development thrust. The university realizes its mission within the definite territory by allotting various contributions into development of the region.

\section{Rectors and universities' social responsibility}

Please note that by today all rectors of federal universities (except for Far-Eastern University) took direct part in their formation by designing development strategies and agreeing their provisions with official authorities of sub-federal entities, federal circuits and federal authorities. So, we can consider it justified that their idea about the place of definite federal universities in the modern education system and regions was inherently laid into conceptions of their functioning and development, in the basis of a new corporate culture and in development of partner relations with the official authorities and business community.

At the same time, as civil officers thought, commitments to results and significant financial, statutory and legal supports of newly-created universities from official authorities were to give competitive strengths to the management of new universities in the market of educational services and in world ratings.

First, in most cases the administrative integration results not in an amalgamation but rather in a "takeover" (oppression) by one university culture of others, frequently with loss of some part of their competitive advantages. For instance, during the period of 2009-2014, among nine federal universities five showed significant fall-downs of their positions in the national rating, two did not show any changes and only SVFU's position grew up allowing the university to remain within "top forty".

Second, subordination of a traditional university culture based on unique decades-long corporate values to the quite formal "commitment to results", as civil clerks from Russia's Ministry of Education and Science see it, could not but cause further "oppression" of another portion of the values in the sphere of relations between universities' management and their academic teaching staff.

One of leading factors of changes occurring in the scope of corporate values became appointment for offices of federal universities' rectors those persons who, as leaders, were to subdue them to the 
http://dx.doi.org/10.15405/epsbs.2017.01.83

eISSN: 2357-1330 / Corresponding Author: Andrei G. Shelomentsev

Selection and peer-review under responsibility of the Organizing Committee of the conference

new "result-focused" strategy, which, essentially, boils down to occupying certain positions in international ratings and achieving indicators established by Russia’s Ministry of Education and Science.

We reviewed personalities of federal universities' rectors from the point of view: first, of their understanding of the specific essence of the educational activity by identification of their working experience in the academic setting; second, of availability of their relations with the region of the university's location as with the place where they received their education and, consequently, employment, that, to our mind, could contribute to formation of the university's socially responsible policy in relation to the region. As the analysis showed, seven federal university's rectors of ten are connected with the region by universities and institutes where they received higher education and finished post-graduate studies; seven of them possess academic doctor's degrees; four of them have been working in universities for a long time (over 10 years) in various capacities. Six of them have been working for a long time in local authorities of these regions. It allows assuming that such historical connection of the rectors with the region should contribute to formation of real interest and socially responsible attitude to positioning of deferral universities in socio-economic development of sub-federal entities and federal circuits.

Thus, on one hand, integration processes in the national academic setting, in its pursuit to achieving formalized effectiveness, led to loss of identity and corporate values by some universities; and on the other hand, qualification and personal experience of professional activity of most rectors should contribute to adequate understanding of universities' role in regions and in the national economy as a whole.

\section{Universities and regional leaders}

The personality of the regional leader, or, better to say, his/her ideas about significance of the regional education system, universities' position, perspectives of universities' graduates play the determinative role in "university - region" interrelations. Basing on the socio-cultural approach, we assumed that a governor's professional experience has a great impact on the nature of relations between authorities and universities. In this aspect, we singled out as basic attributes: the region of the higher education institution they graduated from; residence in this territory for a relatively long time (over 10 years) and employment in the university. As the analysis showed, from the ten regions' leaders only three graduated from local universities; Governor of Primorye Territory is the only one who has experience of work in a university; five regional leaders live in their territories for quite a long time. As we think, most clearly this factor is revealed in the regions where these three characteristics overlay between each other: it takes place in Republic of Tatarstan, Republic of Sakha (Yakutia) and in Crimea where traditions of national cultures play a considerable role.

Thus, the governors' stand in relation to universities is realized in practice in determination of their "third function" in the regional development strategies. To illustrate it, we analyzed strategies of megaregions (federal circuits).

So, in the basic development lines of Volga Region Federal Circuit up to 2030 the task of forming federal and national research universities is set, as well as increasing of funds allocation for R\&D. At the same time, within "Partnership for enhancing high school's competitive ability" project the task of strengthening of attractiveness of Tatarstan's high schools in the federal and international markets has 
been set. In the strategies of Ural Federal circuit, Ural Federal University is regarded as a scientificinnovation core of the mega-region's efficient innovation system. In the strategy of Siberian Federal circuit, Siberian Federal University is positioned as the largest educational centre of training highskilled specialists and a driver of the region's innovation policy. Southern Federal University is regarded in development programmes of Southern Federal circuit as one of the most important competitive advantages for socio-economic development of the mega-region. In development programmes of FarEastern Federal circuit, Far-Eastern and North-Eastern Federal Universities are positioned as the largest educational centres for training high-skilled specialists and realization of innovation technologies. Taking into account regional specifics, the task of arrangement and coordinating of well-balanced provision of programmes of socio-economic development of the regions with high-skilled specialists, scientific, technical and technological solutions in North-Western Federal circuit has been set to Northern (Arctic) Federal University. The role of Baltic Federal University has been determined as training of specialists for the socio-economic sphere of Kaliningrad Region on basis of applying modern educational techniques, conducting a wide range of fundamental and application of scientific researches. In the strategy of North-Caucasian Federal circuit, the role of North-Caucasian Federal University consists of creation of sectoral clusters integrating the science, production and education, involvement of employers into development of occupational standards, programmes of the new generation, perfecting the career development system. In the strategy of Crimean Federal circuit, Crimean Federal University is regarded as an object of construction and reconstruction. Thus, all federal universities act as powerful education and scientific innovation centres for their regions providing for training of specialists and fulfilling the regions' orders for scientific researches.

As we see, complementarity of regions and universities is built-up or is in process of building-up. The partners "see" each other. At present it is one of the most important development thrusts of Russia's innovative economy. However, mega-regions' strategies should be supplemented with efficient interaction mechanisms in the financial-economic sphere and definite measures of mutual responsibility. This is the only case when federal universities will become not just training centres but also sources of innovation that are promptly implemented in the region's economy. It should be mentioned that all Strategies are concrete, yet they lack the concept of "social responsibility". As a result, the situation occurs when universities' programme documents reflect elements of social responsibility to the regions, while strategies of the regions do not afford to clearly monitor the place of their social responsibility.

\section{Conclusion}

The analysis of materials studied by us which were obtained in course of researches, interviews with heads of universities and institutes, organizations, official authorities, shows that at present understanding of social responsibility to the society is forming is the regions. What conclusions can we make of it?

It is necessary to form the efficiently functioning educational space of the region. An essential task for regions is provision of development and continuous qualitative enhancements of the population life. At the same time, actualizing is the task of elevating living standards on basis of building the 
"knowledge economy" which determines necessity of human resources development and creation of benevolent conditions for innovation activity. In these conditions the university serves to purposes of socialization of population and, in the first line, of the youth, ensuring graduation and continuity of education. Intellectual potential of the university and its scientific schools can and must serve to solving the task of sustainable development of the region, revealing and stimulating of "growth points" of the territory on basis of using the intellectual potential of the youth. In the context of regional development, these functions of the university should be regarded as backbone. Therein the sense of real social responsibility lies.

To realize the principle of social responsibility, it is necessary to ensure active socio-cultural and social-economic interaction of the university and the region as equal partners. Actuality of this line is growing continuously in connection with necessity to develop regional development strategies. The university takes active part in solving this task by elaborating appropriate values, tools and technologies, offering sources of innovative social and economic development of the regional community. The university traditionally acts as a supplier of specialists for enterprises and organizations of the region. Under its influence, formed and supported at the necessary level are requirements and conditions of professional activity of specialists of various branches of the regional economy, and determination of lines, shapes and resources of development of the regional community takes place. However, the universities' potential is much higher. It is connected, first of all, with the existing practice of re-training of authority officials on universities' basis. Here actualization of achievements of academic researches and their implementation into the practice of the regional economy management are necessary. Close relations with the region's infrastructure help in expansion of the educational field and assist in employment of not only young persons but the adult population too via realization of programmes of additional occupational education. It is one of mechanisms of social responsibility realization in a definite region.

Creation of the educational space on basis of social responsibility should be related, first of all, to the fact that a university (institute) is a type of a cultural centre, a core in inter-ethnic relations, and a factor of strengthening the national security. At the same time, the university's functions are quite peculiar: satisfaction of the region's needs in specialists with higher education (formation of the regional elite's core), continuous education of the population; resurrection and maintaining of culturaleducational traditions of the region; creation of specific conditions for expansion of the innovation spectrum in the region's education system, elevating the cultural and educational level of the region's population. One of the most essential tasks in forming of this line is buildup of the system of spiritual and moral upbringing of the population with use of the historic-cultural potential of territories. It is an indispensible thing for formation of social responsibility.

In a wide sense, social responsibility as a function of the university is aimed not only at satisfying the population's needs in higher education services but at strengthening interrelations of higher education with the region's economic complex. In this connection, issues of rational correlation of general educational, humanitarian, general professional and special programmes of training specialists, including those for the regional economy, should be solved. Close interaction with the regional authorities, representatives of the business sector and public organizations in solving problems and elaborating prospects of socio-economic 
development of the region in line with traditional national values and in the context of historical and sociocultural development of the territory should become an important aspect in strengthening of the university's role in regional development.

Introduction into mentality of heads of high schools, organizations and official authorities the necessity of supporting on social responsibility to residents of the region for development thereof takes a long time. This introduction process should be realized in all programme documents (missions, strategies, development programmes, etc.). It is preferable to recommend inclusion of indexes of relations with regions into universities' ratings, and inclusions of relations with universities into regions' ratings.

Social responsibility is not a thing to measure with a certain instrument. It is expressed in deeds, qualitative training of specialists, efficient production, decreases of the number of malefactions, etc. It is necessary to be introduced into this process. We need understanding of new values complying with a socially oriented economy, and universities should become carriers and distributors thereof.

Thus, further development of universities' and regions' social responsibility on basis of formation of the common value paradigms is a governing factor which ensures competitive advantages, both of the former and latter. At the same time, in course of transformation of the national system of education, the values need to be subject of constant innovations which modify relations of all parties. Basic sources of novations in the sphere of values are: management generational change; change of owners and of capital corporate structure; change of the national regulatory framework; structural changes in the branch (technological breakthroughs); fusing of participants into associations, unions, etc. Constant perfecting of the system of values is a prerequisite of maintaining competitive ability of universities and efficiency of authorities. Governmental policy in the sphere of education should be aimed at formation of optimal education structures which are factorial determinants of the national economy's competitive ability in a long-term range.

\section{Acknowledgements}

The study was conducted in framework of "Socio-economic factors and innovation mechanisms of realization of policy of dynamic development of Far East" research work (public assignment 2014/292).

\section{References}

Blagov, Y.E. (2010). Corporate social responsibility: evolution of the concept. Graduate School of Management, St. Petersburg.

Bowen, H. R. (1953). The social responsibility of the businessman. Harper and Row, New York.

Carroll, A. B. (1991). The pyramid of corporate social responsibility: Toward the moral management of organizational stakeholders. Business Horizons, Vol. 34 (4), pp. 39-48.

Chicharro, M.N., Carrillo, I.A. \& Rosa, C.P. (2015). University social responsibility: Empirical study on the reliability of a set of indicators for corporate governance. Innovar, 25 (58), 91-104.

De Deus, R.M. et al (Eds.) (2015). The journey to sustainable universities: In-sights from a Brazilian experience. International Journal of Business Excellence, 8 (2), 146-159.

Far Eastern Federal University Development Programme for 2010 - 2019, Directive of the Government of the Russian Federation No 2300-p. of December 17, 2010 (2010). Far Eastern Federal University. Retrieved from https://www.dvfu.ru/

Freeman, I. and Hasnaoui, A. (2011). The Meaning of Corporate Social Responsibility: The Vision of Four Nations. Journal of Business Ethics, 100, 419-443. 
Hout, M. (2012). Social and Economic Returns to College Education in the United States. Annual Review of Sociology, 38, 379-400.

Immanuel Kant Baltic Federal University Development Programme for 2011 - 2020, Directive of the Government of the Russian Federation No 745-p of July 13, 2011. (2011). Immanuel Kant Baltic Federal University Retrieved from https://www.kantiana.ru/federal/progamm_bfu/program_bfu.pdf

Kazan (Volga region) Federal University Development Programme for 2010 - 2019, Directive of the Government of the Russian Federation No 1543-p of September 13, 2010. (2010). Kazan University. Retrieved from http://kpfu.ru/cpr/sistema-monitoringa-programmy-razvitiya-kfu/programma

Kudryashov, Y. (2014). Federal University development program: the need to up-date., Vestnik of Northern (Arctic) Federal University. Editorial Panel of "Natural Sciences", 3, 135-140.

Lavrov, A.A. \& Stepanova, N.P. (2012). Education regionalization as realization direction for social responsibility of educational institutions. Fundamental research, 9, 613-618.

Moratis, L. and Cochius, T. (2011). ISO 26000 the Business guide to the new Standard on Social Responsibility, Greenleaf publishing, UK.

Morozova, I. S. (2011). Corporate Social Responsibility in Information Society, Knowledge. Understanding. Skill, No.6 Retrieved from From http://www.zpu-journal.ru/e-zpu/2011/6/Morozova_Corporate-Social-

Responsibility/

North Caucasian Federal University Development Programme for 2012 - 2021, Directive of the Government of the Russian Federation No 854-p of May 28, 2012. (2012). North Caucasian Federal University. Retrieved from http://www.ncfu.ru/uploads/doc/razvitie.pdf

North-Eastern Federal University Development Programme for 2010 - 2020, Directive of the Government of the Russian Federation No 1775-p. of September 10, 2015 (2015). North-Eastern Federal University. Retrieved from http://www.s-vfu.ru/upload/iblock/709/709a0da7bb80a22fcdfe5c785f821edd.pdf

Northern (Arctic) Federal University Development Programme for 2010 - 2020, Directive of the Government of the Russian Federation No 1604-p. of August 19, 2015/ (2015). Northern (Arctic) Federal University. Retrieved from http://narfu.ru/upload/medialibrary/614/development_program_2010_2020.pdf

Paleari, S., Donina, D. and Meoli, M. (2015). The role of the university in twenty-first century European society. Journal of Technology Transfer, 40 (3), pp. 369-379.

Rating universities in Russia 2014/2015. (2015). National ranking university. Retrieved from www.univerrating.ru

Shakhovoy, V. (2008).Social development and the social responsibility as conditions of effective management of the enterprise. Management and Business Administration, 4, 152-165.

Shokola, Y.V. and Shraer, A.V. (2015). Corporate social responsibility in the sys-tem of socioeconomic relationship: genesis of formation and evolution. Actual problems of Economics and Management, 1(5), 129-133.

Siberian Federal University Development Programme for 2011 - 2021, Directive of the Government of the Russian Federation No 1455-p of July 25, 2015. (2015). Siberian Federal University. Retrieved from http://about.sfukras.ru/node/8232

Smirnov, A. (2012). Social responsibility of universities in the regional community. Rectors Council, 7, 26-32.

Southern Federal University Development Programme for 2011-2021, Directive of the Government of the Russian Federation No 968-p of June 3, 2011 (2011) Southern Federal University. Retrieved from http://sfedu.ru/docs/ufudoc/programm_25-07-15.pdf

The national rating of universities (2015) Retrieved from http://www.univer-rating.ru/rating_common.asp?per=1

The strategy of the European Commission on CSR for 2011-2014 (2011). EUR-Lex: Access to European Union law. Retrieved from http://eur-lex.europa.eu/LexUriServ/LexUriServ.do?uri=COM:2011:0681:FIN:en:PDF

Universities Act 645/1997 (Amendments up to 715/2004 included) (2004). Ministry of Education and Culture, Helsinki. Retrieved from http://www.minedu.fi/export/sites/default/OPM/Koulutus/

Ural Federal University Development Programme for 2010-2019, Directive of the Government of the Russian Federation No 1693-p of October 13, 2010. (2010). Ural Federal University. Retrieved from http://strategy.urfu.ru/programma-razvitia/

Vernadsky, V.I. Crimean Federal University Development Programme for n 2015 - 2024 (2015) Directive of the Government of the Russian Federation No 745-p of April 27, 2015. Retrieved from http://www.cfuv.ru/programma-razvitiya-2

WBCSD Stakeholder Dialogue on CSR (1998) WBCSD, Netherlands. Retrieved from www.wbcsd.org/work159program/businessrole/previous-work/corporate-social-responsibility.aspx

Zabayev, I. \& Pavlyutkin, I. (2014). University and Two Meanings of Responsibility: Objectification of Social Effects of Educational Institutions (by the example of a survey among graduates of an Orthodox university). Educational Studies, 2, 202-218. 